\title{
FREEZE-THAW AND FIRE RESISTANCE OF GEOPOLYMER MORTAR BASED ON NATURAL AND WASTE POZZOLANS
}

\author{
F. NURHAYAT DEGIRMENCI
}

Balikesir University, Architecture Faculty, Department of Architecture, Cagis campus, 10145, Balikesir, Turkey

"E-mail: nurhayat@balikesir.edu.tr

Submitted July 14, 2017; accepted September 18, 2017

\begin{abstract}
Keywords: Fly ash, Ground granulated blast furnace slag, Natural zeolite, Alkaline activator solution
The purpose of this research was to investigate the resistance of pozzolan-based geopolymer mortars subjected to high temperatures and freeze-thaw cycles. Low calcium fly ash and granulated blast furnace slag as waste pozzolans and natural zeolite as a natural pozzolan were used as base materials for producing geopolymer mortar. The other purpose the research was to study the effect of alkaline activator ratio $\left(\mathrm{Na}_{2} \mathrm{SiO}_{3} / \mathrm{NaOH}\right)$ on the performance of pozzolan-based geopolymer mortar specimens subjected to extreme temperatures. The influence of high temperatures on the properties of mortars was investigated at 300, 600, and $900^{\circ} \mathrm{C}$. Fire and freeze-thaw and resistance of mortars were investigated in terms of visual appearance, weight loss and residual compressive strength. The minimal values of the residual compressive strength were obtained at $900^{\circ} \mathrm{C}$ for all mixtures. The residual compressive strength of all specimens was lower than the values obtained for specimens not subjected to any freeze-thaw resistance test, except those containing GGBS. The $\mathrm{Na}_{2} \mathrm{SiO}_{3} / \mathrm{NaOH}_{\mathrm{ratios}}$ of the alkaline activator solution used to prepare the geopolymer mortars have an effect on the weight losses and residual compressive strengths of the specimens subjected to high temperatures and freeze-thaw cycles. As the $\mathrm{Na}_{2} \mathrm{SiO}_{3} / \mathrm{NaOH}$ ratios increased, the weight and strength losses decreased.
\end{abstract}

\section{INTRODUCTION}

Portland cement is the world's most widely used construction material, although its production is one of the leading sources of greenhouse gas emissions. The cement industry is held responsible for around $5 \%$ of man-made $\mathrm{CO}_{2}$ emissions, because the production of one ton of Portland cement releases about one ton of $\mathrm{CO}_{2}$ into the atmosphere [1-3]. Due to the rapidly growing worldwide population and consequently increasing demand for housing, in construction industry, cement consumption for concrete production is increasing each year. This means an increase in the amount of $\mathrm{CO}_{2}$ emissions from cement production. For this reason, it is necessary to find an alternative to cement for the production of environmentally friendly building materials. In this respect, geopolymer offers certain advantages in terms of environment. Because its main ingredient is an industrial by-product, the geopolymer binder technology requires much less energy to produce and results in significantly less carbon dioxide emissions than Portland cement, making the environment a more sustainable option. It was reported that $\mathrm{CO}_{2}$ emissions due to the production of geopolymer are generally 60 - $80 \%$ lower than Portland cement [4]. Until now, geopolymers have mostly relied on low calcium fly ash or ground granulated blast furnace slag. Most of the previous studies on geopolymer concrete and mortars are about the engineering properties of low calcium fly ash and slag based-geopolymer concrete [5-8]. On the other hand, only limited information is available the use of natural zeolite in production of geopolymer concrete or mortar $[9,10]$. Up to now only a few studies have investigated the effect of the concentration of the alkaline solution on the strength and durability properties of the geopolymer concrete [11-13]. Moreover, there is limited literature describing the effects of alkaline activator ratios $\left(\mathrm{Na}_{2} \mathrm{SiO}_{3} / \mathrm{NaOH}\right)$ on durability properties of geopolymer mortar $[14,15]$. In previous studies, there are almost no studies describing the effects of alkaline activator ratios on freeze-thaw and fire resistance of geopolymer mortars. In this study, low calcium fly ash (FA), ground granulated blast furnace slag (GGBS) and natural zeolite (NZ) which are rich in silica and alumina have full potential to be used as the base material for geopolymer mortar and they are replaced as $50 \%$ and $100 \%$. It has been always a prospective goal to pursue the better mortars with $100 \%$ industrial by-products to meet the requirements for low cost, low energy consumption, reduced environmental pollution, improved engineering properties and superior durability. The majority of this research focuses on investigating the effect of alkaline 
activator ratios $\left(\mathrm{Na}_{2} \mathrm{SiO}_{3} / \mathrm{NaOH}\right)$ on the freeze-thaw and fire resistance of geopolymer mortars based on FA, GGBS and NZ.

Geopolymer materials have been found to be excellent resistance to temperature extremes. Geopolymers are generally resistant both to high temperatures over $1000^{\circ} \mathrm{C}$ and to low temperatures due to high level of freeze-thaw. Freeze-thaw resistance is an extremely important factor in determining the durability of concrete structures, but most of the reported freeze-thaw resistant work has been carried out on geopolymer materials derived from class-F fly ash and granulated slag. It has been observed that compressive strengths of the geopolymer samples subjected to 150 freeze-thaw cycles are reduced by only $30 \%$ of the test values not subjected to freeze-thaw cycles [16]. According to Yunsheng and Wei [17] the alkali activated fly ash can withstand 2.2 times as much freeze-thaw cycle as compared with concrete made from Portland cement having the same compressive strength. Krivenko [18] investigated the effect of different type of alkaline activator solutions on the freezing-thaw resistance and he reported that the sodium silicate activated slag concrete was largely resisting due to the less porous structure. Bortnovsky et al. [19] analyzed the resistance of alkali activated slag binders reporting a high compressive strength even after freeze-thaw 100 cycles. Brooks et al. [20] reported a low rate of scaling in alkali activated class F fly ashbased materials after 40 cycles of air-entrained freezethaw cycles. The results based on weight loss and visual changes in the specimens indicated that alkali activated fly ash has a good resistance to freeze-thaw cycles. It was also found that air-entraining admixtures commonly used to increase the freeze-thaw durability of Portland cement concrete did not increase the durability of alkali activated fly ash materials. Heng [21] reported that alkali activated slag concrete showed excellent freeze-thaw resistance, thus fitting their application in tunnel lining in extremely cold regions.

Geopolymers are generally believed to perform better than the conventional concretes in fire, due to their ceramic-like properties [22-24]. Geopolymer based cement possesses excellent high temperature resistance up to $1200^{\circ} \mathrm{C}$ without sudden properties degradation. Topcu and Toprak [25] stated that geopolymers have good fire resistance up to $1000^{\circ} \mathrm{C}$ without emitting toxic gas. Portland cement shows a weak performance when subjected to a thermal treatment and begins to disintegrate when the temperature rises above $300^{\circ} \mathrm{C}$ [26]. The geopolymer based alkali activated fly ash exposed to the effect of high temperatures loses a substantial part of its strength which dropped to $40 \%$ of its original value [27]. The highest compressive strength is obtained when the temperature is $200^{\circ} \mathrm{C}$. The strength starts dropping once the temperature is over $400^{\circ} \mathrm{C}$. The lowest values of the residual strength were observed in the temperature range of 600 to $800^{\circ} \mathrm{C}$, they were due to the presence of the melt that started forming. While Portland cement mortar degrades and degenerates at high temperature, it has been found from different studies that fly ash geopolymer mortar can maintain its desired compressive strength even at $400^{\circ} \mathrm{C}$ [28]. According to Pan et al. [29] geopolymers are inherently fire resistant due their polymeric-silicon-oxygen-aluminum framework. Krivenko and Guziy [30] found that alkali activated binders show a high performance in the resistance to fire, thus suggesting that this material is suitable for use in works with a high fire risk like tunnels and tall buildings.

\section{EXPERIMENTAL}

\section{Materials}

Low-calcium Class F fly ash (FA) as a by-product of burning coal conforming to ASTM C 618 [31], ground granulated blast furnace slag (GGBS) as a byproduct of iron and steel production conforming to TS EN 15167-1 [32] and natural zeolite-clinoptilolite (NZ) was used as the base materials in this study. The chemical composition of FA, GGBS and NZ are shown in Table 1. Silica sand graded similar to standard sand [33] was used as fine aggregate in the production of gepolymer mortar. The grading curve of used silica sand is presented in Figure 1. To activate the base materials, the mixture of sodium hydroxide $(\mathrm{NaOH})$ solution and sodium silicate $\left(\mathrm{Na}_{2} \mathrm{SiO}_{3}\right)$ solution was used as alkaline activator solution. The sodium silicate solution (8\% $\mathrm{Na}_{2} \mathrm{O}, 27 \% \mathrm{SiO}_{2}$ and $\left.65 \% \mathrm{H}_{2} \mathrm{O}\right)$ and sodium hydroxide $(\mathrm{NaOH})$ in flakes $98 \%$ purity were purchased from a local supplier in bulk. Distilled water was used to dissolve sodium hydroxide pellets to prevent any effect of unknown contaminants. Sodium hydroxide solution of required molarity and sodium silicate in liquid form were mixed and stored at room temperature of $23 \pm 2{ }^{\circ} \mathrm{C}$ for $24 \mathrm{~h}$ before its use.

Table 1. Chemical composition of base materials used.

\begin{tabular}{lccc}
\hline \multirow{2}{*}{$\begin{array}{l}\text { Definition } \\
\text { notation }\end{array}$} & \multicolumn{3}{c}{ Chemical compositions (\%) } \\
\cline { 2 - 4 } & FA & GGBS & NZ \\
\hline $\mathrm{SiO}_{2}$ & 52.90 & 41.67 & 68.3 \\
$\mathrm{Al}_{2} \mathrm{O}_{3}$ & 25.50 & 11.56 & 10.97 \\
$\mathrm{Fe}_{2} \mathrm{O}_{3}$ & 8.70 & 0.90 & 1.02 \\
$\mathrm{CaO}$ & 4.75 & 35.58 & 3.24 \\
$\mathrm{MgO}$ & 3.10 & 5.28 & 1.01 \\
$\mathrm{Na}_{2} \mathrm{O}$ & 0.40 & 0.68 & 0.17 \\
$\mathrm{~K}_{2} \mathrm{O}$ & 2.00 & 1.00 & 2.4 \\
$\mathrm{SO}_{3}$ & 2.90 & 0.10 & - \\
$\mathrm{Cl}^{-}$ & 0.002 & 0.0105 & - \\
$\mathrm{FreeCaO}^{-}$ & 0.88 & - & - \\
$\mathrm{Reactive} \mathrm{SiO}$ & 34.06 & - & 54.93 \\
Reactive $\mathrm{CaO}$ & 0.60 & 82.53 & - \\
LOI & 0.53 & 0.01 & 12.90 \\
\hline
\end{tabular}




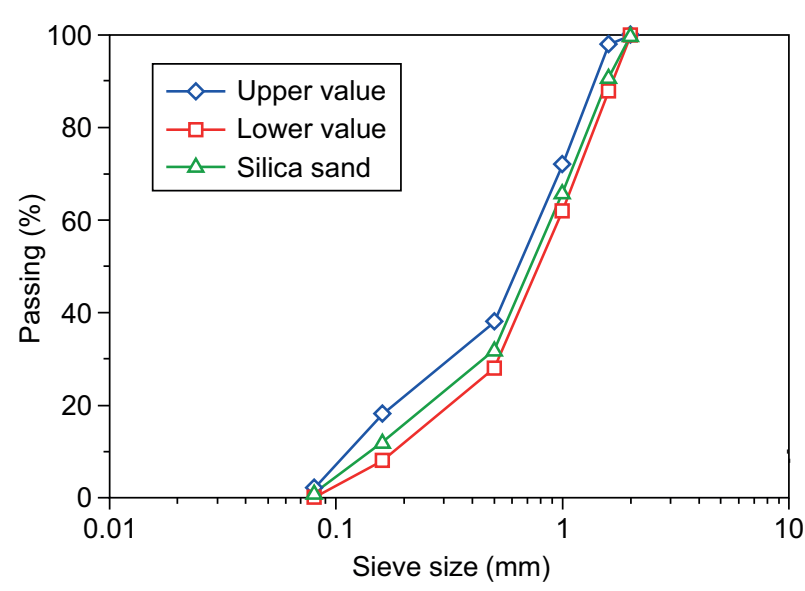

Figure 1. Gradation curve of silica sand.

\section{Preparation of geopolymer mortar specimens}

Geopolymer mortar can be produced by adopting the conventional techniques used in the manufacture of cement mortar. The weight ratio of sand to base material was fixed at 3.0 for all mixtures. Gopolymer mortars were prepared with a fixed alkaline activator solution to base solid material ratio of 0.5 . The slump flows of all fresh mortars were controlled at $110 \pm 5 \%$ according to ASTM C230 [34] by using extra water. The mix proportions of geopolymer mortars are described in Table 2. The concentration of alkali activator solution used in experimental study was 10 molar. The ratios of alkaline activator solution $\left(\mathrm{Na}_{2} \mathrm{SiO}_{3} / \mathrm{NaOH}\right)$ by mass were 1.0 , 2.0 and 3.0. In the laboratory, the base materials and sand were dry mixed in Hobart mixer for about three minutes. Then alkaline activator solution was added along with extra water to maintain the workability of geopolymer mortars. The mixture was mixed for another five minutes. After the slump flow test, the fresh mortar was cast and compacted by the usual methods used in the case of cement mortar. The specimens were wrapped with plastic sheets to prevent from moisture loss. After 24 hours cured in the molds, all mortar specimens were demolded and then cured at room temperature of $23 \pm 2{ }^{\circ} \mathrm{C}$ until the testing day.

\section{Testing}

Freeze-thaw and fire resistance of pozzolan-based geopolymer mortars were investigated in terms of visual appearance, weight loss and the residual compressive strength. Freeze-thaw resistance was tested on the $50 \mathrm{~mm}$-cube specimens after 28 days curing in room temperature. In this test the mortar specimens were put in deep freezer at $-20^{\circ} \mathrm{C}$ for $4 \mathrm{~h}$ during freezing and in water at room temperature for $4 \mathrm{~h}$ during the thawing period. The freeze-thaw test cycle was repeated for 25 times and then compression test was conducted. Also three specimens from each mixture were kept at room temperature during the freeze-thaw test of the other specimens and all mortar specimens were tested at the same age. The present freeze-thaw experiments

Table 2. Mix proportions of geopolymer mortars.

\begin{tabular}{|c|c|c|c|c|c|c|c|c|c|c|c|}
\hline \multirow[t]{2}{*}{ Mix ID } & \multicolumn{2}{|c|}{ NZ } & \multicolumn{2}{|c|}{ FA } & \multicolumn{2}{|c|}{ GGBS } & Sand & $\begin{array}{l}\text { Extra water } \\
\text { added }\end{array}$ & $\begin{array}{l}\mathrm{Na}_{2} \mathrm{SiO}_{3} \\
\text { solution }\end{array}$ & $\mathrm{NaOH}$ & \multirow{2}{*}{$\begin{array}{c}\mathrm{Na}_{2} \mathrm{SiO}_{3} \text { - to- } \\
\mathrm{NaOH} \text { ratio } \\
\text { by mass }\end{array}$} \\
\hline & $(\%)$ & $\left(\mathrm{kg} \cdot \mathrm{m}^{-3}\right)$ & $(\%)$ & $\left(\mathrm{kg} \cdot \mathrm{m}^{-3}\right)$ & $(\%)$ & $\left(\mathrm{kg} \cdot \mathrm{m}^{-3}\right)$ & \multicolumn{4}{|c|}{$\left(\mathrm{kg} \cdot \mathrm{m}^{-3}\right)$} & \\
\hline$\overline{\mathrm{NZ}}$ & 100 & 510 & - & - & - & - & 1530 & 80 & 127.5 & 127.5 & 1.0 \\
\hline FA & - & - & 100 & 510 & - & - & 1530 & 40 & 127.5 & 127.5 & 1.0 \\
\hline GGBS & - & - & - & - & 100 & 510 & 1530 & - & 127.5 & 127.5 & 1.0 \\
\hline $\mathrm{NZ}+\mathrm{FA}$ & 50 & 255 & 50 & 255 & - & - & 1530 & 40 & 127.5 & 127.5 & 1.0 \\
\hline $\mathrm{NZ}+\mathrm{GGBS}$ & 50 & 255 & - & - & 50 & 255 & 1530 & 40 & 127.5 & 127.5 & 1.0 \\
\hline $\mathrm{FA}+\mathrm{GGBS}$ & - & - & 50 & 255 & 50 & 255 & 1530 & - & 127.5 & 127.5 & 1.0 \\
\hline$\overline{\mathrm{NZ}}$ & 100 & 510 & & - & & - & 1530 & 90 & 170 & 85 & 2.0 \\
\hline FA & - & - & 100 & 510 & - & - & 1530 & 40 & 170 & 85 & 2.0 \\
\hline GGBS & - & - & - & - & 100 & 510 & 1530 & - & 170 & 85 & 2.0 \\
\hline $\mathrm{NZ}+\mathrm{FA}$ & 50 & 255 & 50 & 255 & - & - & 1530 & 40 & 170 & 85 & 2.0 \\
\hline $\mathrm{NZ}+\mathrm{GGBS}$ & 50 & 255 & - & - & 50 & 255 & 1530 & 40 & 170 & 85 & 2.0 \\
\hline $\mathrm{FA}+\mathrm{GGBS}$ & - & - & 50 & 255 & 50 & 255 & 1530 & - & 170 & 85 & 2.0 \\
\hline $\mathrm{NZ}$ & 100 & 510 & - & - & - & - & 1530 & 90 & 191.25 & 63.75 & 3.0 \\
\hline FA & - & - & 100 & 510 & - & - & 1530 & 40 & 191.25 & 63.75 & 3.0 \\
\hline GGBS & - & - & - & - & 100 & 510 & 1530 & 40 & 191.25 & 63.75 & 3.0 \\
\hline $\mathrm{NZ}+\mathrm{FA}$ & 50 & 255 & 50 & 255 & - & - & 1530 & 20 & 191.25 & 63.75 & 3.0 \\
\hline NZ+GGBS & 50 & 255 & - & - & 50 & 255 & 1530 & 20 & 191.25 & 63.75 & 3.0 \\
\hline $\mathrm{FA}+\mathrm{GGBS}$ & - & - & 50 & 255 & - & 255 & 1530 & 20 & 191.25 & 63.75 & 3.0 \\
\hline
\end{tabular}


were limited to 25 cycles due to time constraints, but this was sufficient to show that the freeze-thaw resistance of the present NZ-based geopolymer mortar is lower than the other geopolymer mortars. The residual compressive strength was calculated as percentage of initial compressive strength. The compressive strength test in accordance to ASTM C109 [35] was conducted on geopolymer specimens after freeze-thaw test. Compressive strength measurements were carried out using ELE International ADR 3000 hydraulic press with a capacity of $3000 \mathrm{kN}$. Before subjecting the specimens to the freeze and thaw cycles, they were weighed.

For fire resistance $50 \mathrm{~mm}$ cube specimens were used after 28 day curing and geopolymer mortar specimens were put into an electric furnace in room temperature. Geopolymer mortar specimens were subjected to heat treatment in the furnace at 300,600 , and $900^{\circ} \mathrm{C}$ at an incremental rate of $5^{\circ} \mathrm{C}$ per minute from room temperature for 2 hours. Then the specimens were allowed to cool down for 24 hours at room temperature inside the furnace and tested for their compressive strengths after that. In this test, the weight loss also was measured while the specimens were exposed to increasing temperatures.

\section{RESULTS}

\section{Freeze-Thaw Resistance}

After 25 cycles, body disruption or deformation could not be detected in geopolymer specimens. The weight loss of geopolymer mortars after 25 of freezethaw cycles is shown in Figure 2. The influence of freeze-thaw test on the weight loss of NZ based geopolymer mortar is larger than that on the weight loss of GGBS and FA based geopolymer mortars. After 25 cycles of freeze-thaw, the weight losses were $22.9 \%$, $8.46 \%$ and $5.16 \%$ for NZ, FA and GGBS specimens respectively, for $\mathrm{Na}_{2} \mathrm{SiO}_{3} / \mathrm{NaOH}: 1.0$ while the weight losses were $15.34 \%, 5.30 \%$ and $4.11 \%$ for NZ, FA and GGBS specimens respectively, for $\mathrm{Na}_{2} \mathrm{SiO}_{3} / \mathrm{NaOH}: 3.0$. The addition of FA and GGBS to NZ-based mortar by $50 \%$ reduced the weight loss of mortars. Besides, the $\mathrm{Na}_{2} \mathrm{SiO}_{3} / \mathrm{NaOH}$ ratios of alkaline activator solution were found to be effective on weight loss. As the $\mathrm{Na}_{2} \mathrm{SiO}_{3} /$ $\mathrm{NaOH}$ ratios of the alkaline activator solution increase, the weight losses of geopolymer mortars decrease.

Figure 3 shows the residual compressive strength of geopolymer mortars after freeze-thaw test. The residual compressive strength values of all mortar specimens were smaller after 25 of freeze-thaw cycles as compared with the values obtained for the specimens without any freeze-thaw test. The residual compressive strength values of NZ-based geopolymer mortars were found to be lower than the residual compressive strength values of FA-based and GGBS-based mortars after the action of the same cycles of freeze-thaw. The strength of the NZ-based geopolymer specimens after 25 freeze-thaw cycles dropped to about $74 \%$ of that determined after the same period of time. The residual compressive strength values of NZ-based specimens were $26.12 \%$, $36.73 \%$ and $49.94 \%$ for $\mathrm{Na}_{2} \mathrm{SiO}_{3} / \mathrm{NaOH}: 1.0, \mathrm{Na}_{2} \mathrm{SiO}_{3} /$ $\mathrm{NaOH}: 2.0$ and $\mathrm{Na}_{2} \mathrm{SiO}_{3} / \mathrm{NaOH}: 3.0$ respectively. These values were $82.08 \%, 85.47 \%$ and $89.67 \%$ for FA based specimens for $\mathrm{Na}_{2} \mathrm{SiO}_{3} / \mathrm{NaOH}: 1.0, \mathrm{Na}_{2} \mathrm{SiO}_{3} /$ $\mathrm{NaOH}: 2.0$ and $\mathrm{Na}_{2} \mathrm{SiO}_{3} / \mathrm{NaOH}: 3.0$, respectively. The maximum residual compressive strength values were obtained for GGBS specimens after 25 freeze-thaw cycles. The residual compressive strength of GGBS specimens were $97.94 \%, 99.45 \%$ and $100 \%$ for $\mathrm{Na}_{2} \mathrm{SiO}_{3} / \mathrm{NaOH}: 1.0, \mathrm{Na}_{2} \mathrm{SiO}_{3} / \mathrm{NaOH}: 2.0$ and $\mathrm{Na}_{2} \mathrm{SiO}_{3} /$ $\mathrm{NaOH}: 3.0$, respectively. Addition of $50 \% \mathrm{FA}$ and GGBS to NZ-based mortars increased the residual compressive strength values. Glukhovsky [18] and Krivenko [36] investigated the influence of different alkaline activator solutions on freeze-thaw resistance. It has been reported that sodium silicate-activated slag concrete exhibited the greatest resistance, because of its less porous structure.

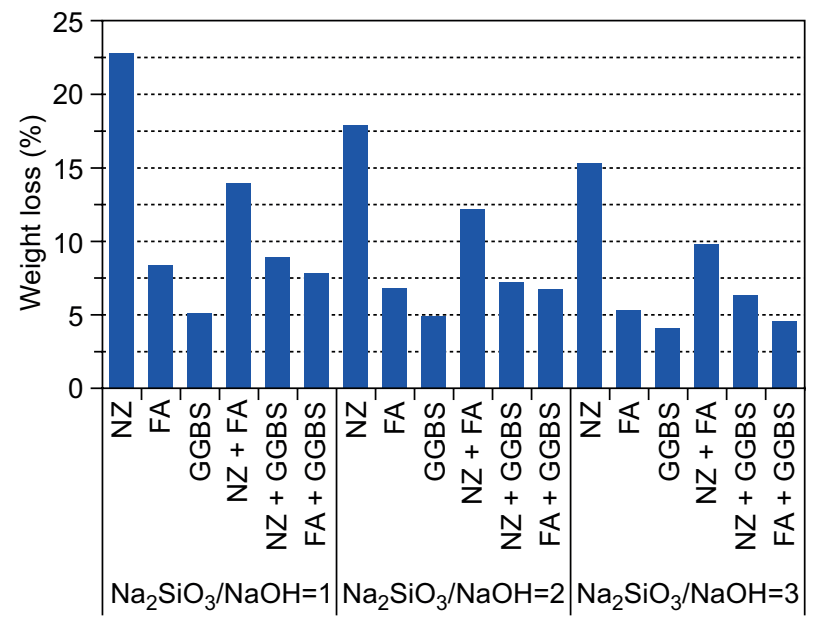

Figure 2. Weight loss of geopolymer mortars after 25 of freezethaw cycles.

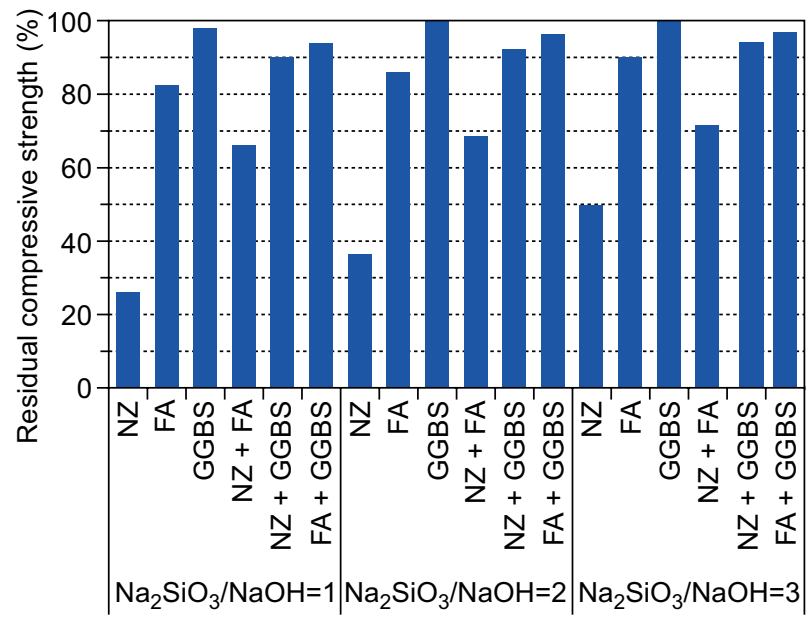

Figure 3. Residual compressive strength of geopolymer mortars after 25 of freeze-thaw cycles. 
The $\mathrm{Na}_{2} \mathrm{SiO}_{3} / \mathrm{NaOH}$ ratios of the alkaline activator solution used to prepare geopolymer mortars have an effect on both weight loss and residual strength of the specimens subjected to freeze-thaw test. As the $\mathrm{Na}_{2} \mathrm{SiO}_{3} /$ $\mathrm{NaOH}$ ratios increased, the weight and strength losses of the specimens exposed to 25 of freeze-thaw cycles decreased.

\section{Fire resistance}

Fire resistance of geopolymer mortars was determined in terms of visual appearance, weight loss and residual compressive strength. The influence of high temperatures on the properties of geopolymer mortars was investigated at temperatures of 300,600 , and $900^{\circ} \mathrm{C}$. Figures 4-6 show the illustration of color change and cracking in geopolymer specimens after high temperature exposure. There was no visible effect on the surface of the specimens heated up to $600^{\circ} \mathrm{C}$. The GGBS based geopolymer mortar started to crack when the temperature reached to $900^{\circ} \mathrm{C}$. The cracks were pronounced after $600^{\circ} \mathrm{C}$ and extensively increased at $900^{\circ} \mathrm{C}$. A slight lightening of color was observed in the mortar specimens after the fire exposure especially to $600^{\circ} \mathrm{C}$ and then the color of specimens turned into white after exposure to $900^{\circ} \mathrm{C}$. It was explained that color changes in geopolymer concrete specimens primarily resulted from gradual dehydration of geopolymer mortars. Figure 6c illustrated the crack propagation in GGBS-based geopolymer mortar after exposure to $900^{\circ} \mathrm{C}$. Porosity increases with increasing temperature and the development of voided pores is considered as a direct result of product degradation at extreme temperatures [37].

Weight loss of geopolymer mortars after exposed high temperatures is given in Figure 7. All mortar specimens experienced a rapid decline in percentage of weight after $300^{\circ} \mathrm{C}$. The most weight losses were observed in GGBS specimens at all temperatures. For $\mathrm{Na}_{2} \mathrm{SiO}_{3} / \mathrm{NaOH}: 1.0$, the weight loss values of GGBS specimens were $5.24 \%, 6.73 \%$ and $7.46 \%$ at $300^{\circ} \mathrm{C}$, $600^{\circ} \mathrm{C}$ and $900^{\circ} \mathrm{C}$, respectively. The least weight loss occurred in the NZ specimens. The weight losses of NZ-based geopolymer mortar specimens were $1.41 \%$, $2.65 \%$ and $3.42 \%$ at 300,600 and $900^{\circ} \mathrm{C}$, respectively, for $\mathrm{Na}_{2} \mathrm{SiO}_{3} / \mathrm{NaOH}: 1.0$. The addition of $50 \%$ FA to GGBS reduced the weight loss of specimens exposed to high temperature effects. The weight loss of the specimens reduced from $7.46 \%$ to $7.37 \%$ and $6.29 \%$ for $50 \%$ addition of $\mathrm{NZ}$ and $\mathrm{FA}$ for $\mathrm{Na}_{2} \mathrm{SiO}_{3} / \mathrm{NaOH}: 1.0$ at $900^{\circ} \mathrm{C}$. These values were reduced from $6.68 \%$ to $6.42 \%$ and $5.46 \%$ for $50 \%$ addition of NZ and FA to GGBS-based mortar for $\mathrm{Na}_{2} \mathrm{SiO}_{3} / \mathrm{NaOH}: 3.0$. At higher temperatures, this weight loss is attributed to a dehydration process of the structure [23]. As temperatures increased, weight loss also increased. It was also observed that geopolymer specimens exposed to elevated temperatures do not release toxic fumes. In this study the weight losses were determined in the range of $2-8 \%$. In another study, it was stated that at temperatures up to $1000^{\circ} \mathrm{C}$, there was a weight loss in the range of $5-12 \%$ [23]. The $\mathrm{Na}_{2} \mathrm{SiO}_{3} /$ $\mathrm{NaOH}$ ratios were effective on the weight loss and minimal weight loss was obtained for $\mathrm{Na}_{2} \mathrm{SiO}_{3} / \mathrm{NaOH}: 3.0$.

The residual compressive strength of geopolymer mortars after exposed high temperatures is given in Figure 8 . The residual compressive strength decreases with the increase of temperatures due to the accelerated drying for particular fire duration. The geopolymer mortars exposed to the effect of high temperatures loses a substantial part of its strength value. The loss of compressive strength becomes already obvious at

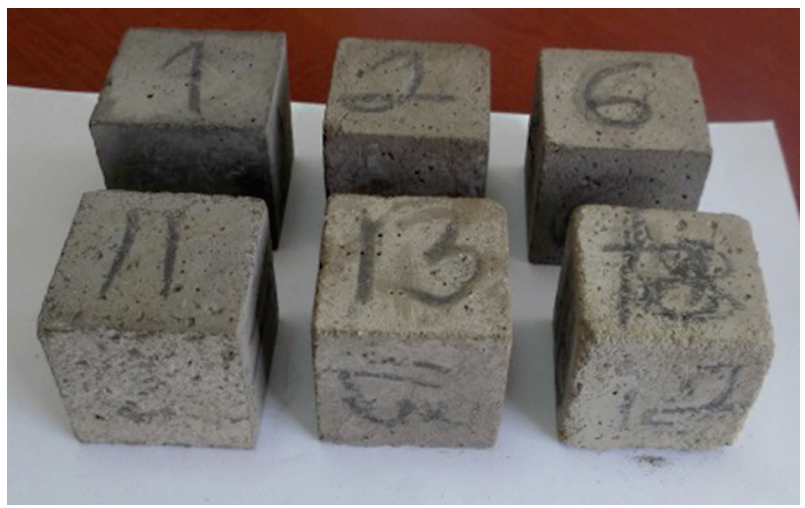

a)

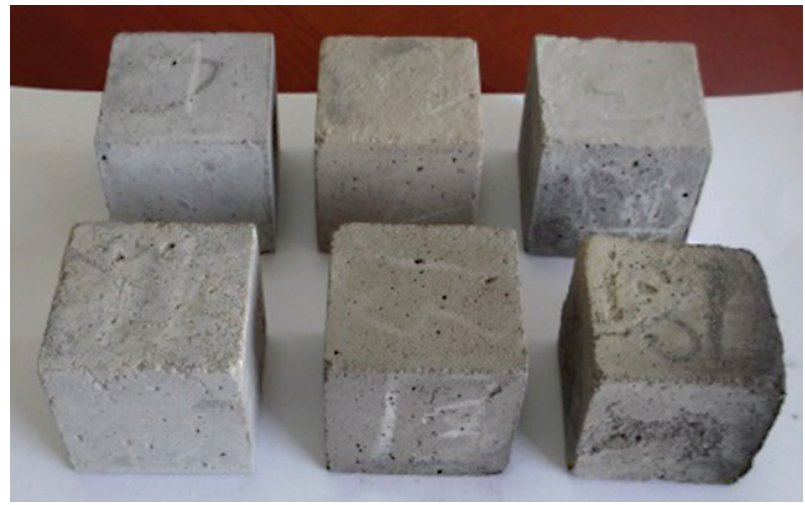

b)

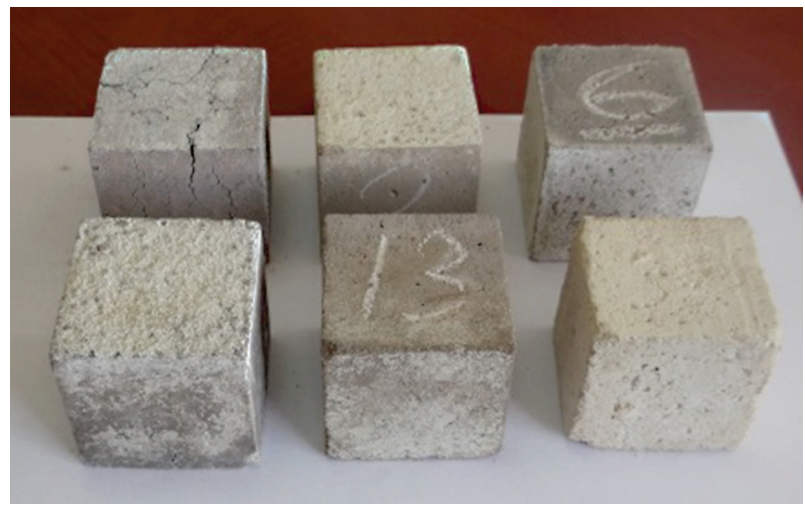

c)

Figure 4. Geopolymer mortar specimens at: a) $300^{\circ} \mathrm{C}$, b) $600^{\circ} \mathrm{C}$ and c) $900^{\circ} \mathrm{C}$. 


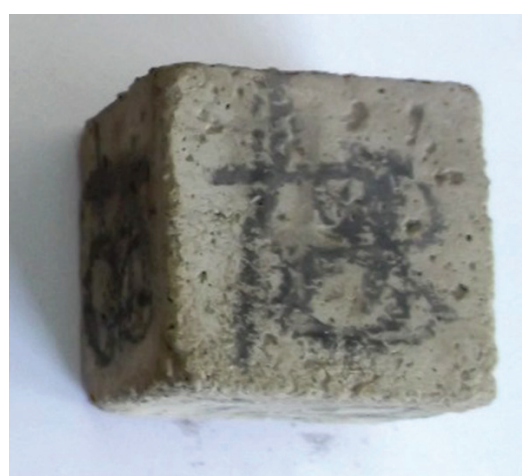

a) $300^{\circ} \mathrm{C}$

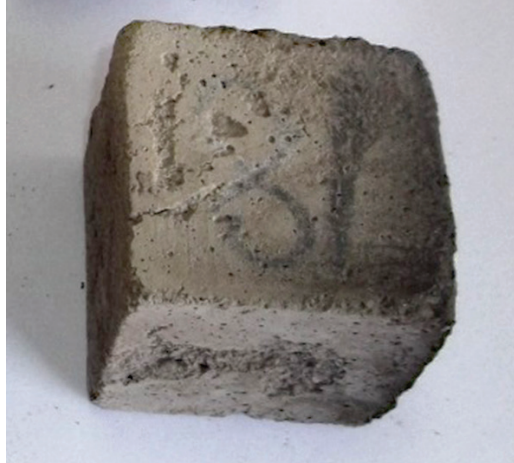

b) $600^{\circ} \mathrm{C}$

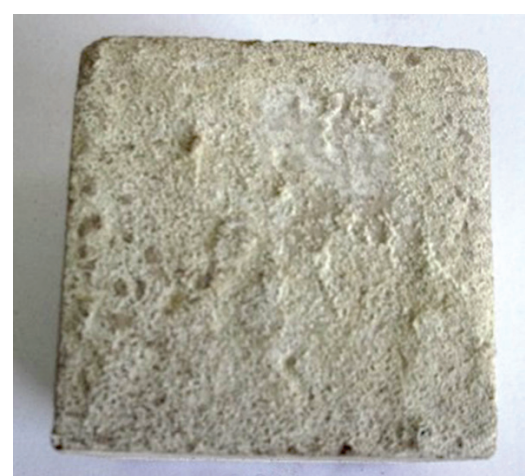

c) $900^{\circ} \mathrm{C}$

Figure 5. NZ based geopolymer specimens at: a) $300^{\circ} \mathrm{C}$, b) $600^{\circ} \mathrm{C}$ and c) $900^{\circ} \mathrm{C}$.

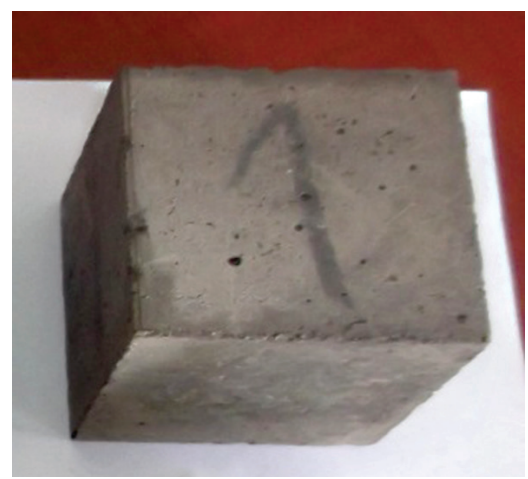

a) $300^{\circ} \mathrm{C}$

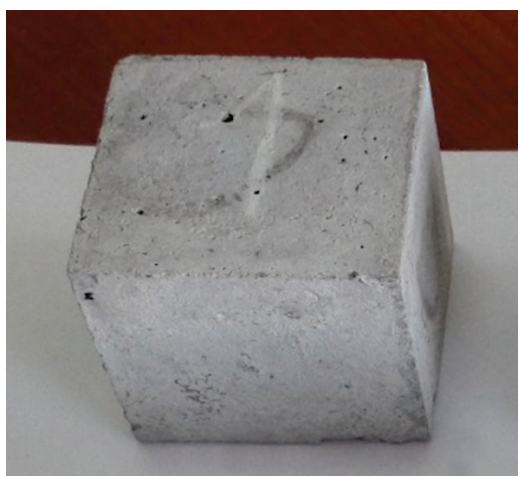

b) $600^{\circ} \mathrm{C}$

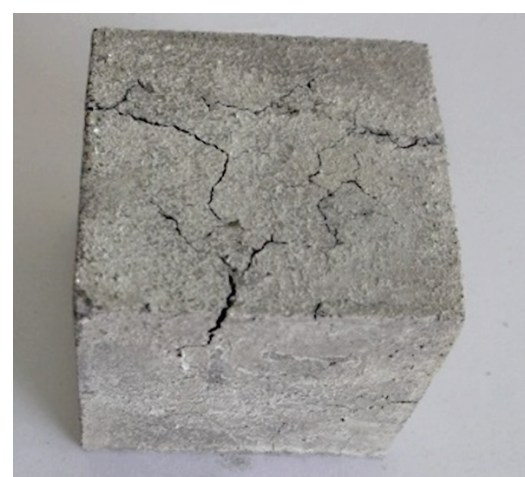

c) $900^{\circ} \mathrm{C}$

Figure 6. GGBS based geopolymer specimens at: a) $300^{\circ} \mathrm{C}$, b) $600^{\circ} \mathrm{C}$ and c) $900^{\circ} \mathrm{C}$.

a temperature of $300^{\circ} \mathrm{C}$. Initially at low temperature $\left(300^{\circ} \mathrm{C}\right)$ the residual strength of geopolymer mortars was observed to be very less due to the evaporation of surface moisture content. As the temperature increases from 300 to $600^{\circ} \mathrm{C}$, the free water content evaporates quickly which leads to internal cracking due to the vapor effect, reducing the residual compressive strength of the geopolymer specimens. Exposure to $600^{\circ} \mathrm{C}$ resulted in a dramatic decrease in the residual compressive strength for geopolymer specimens, which is mainly attributable to the excessive vapor pressure producing large cracks in the specimens. The maximum residual compressive strength for geopolymer mortar specimens was obtained at $300^{\circ} \mathrm{C}$. The minimum compressive strength was obtained at $900^{\circ} \mathrm{C}$ for all mixes. The residual compressive strength of NZ-based mortars after their heat treatment is relatively higher than that of the materials on the basis of FA and GGBS. Turkmen et al. [38] indicated that a significant decrease in the compressive strength was observed in all of the specimens after heating to $700^{\circ} \mathrm{C}$. It was reported that this strength loss is largely attributed to decomposition of calcium hydroxide, which is known to occur between 450 and $500^{\circ} \mathrm{C}$ [39]. The Kong and Sanjayan [23] said that the ratio of fly ash to alkaline activator solution influences the general strength and fire resistance of geopolymer. It was observed that the $\mathrm{Na}_{2} \mathrm{SiO}_{3} / \mathrm{NaOH}$ ratios of alkaline activator solution were also effective in increasing the residual compressive strength. Increasing the $\mathrm{Na}_{2} \mathrm{SiO}_{3} / \mathrm{NaOH}$ ratio leads to more soluble silicates concentration in alkaline activator solution therefore more soluble which play an important role in the geopolymerization process [40].

\section{CONCLUSIONS}

This experimental research investigates fire and freeze-thaw resistance of geopolymer mortars incorporating FA, GGBS and NZ. Based on the test results, the following conclusions can be drawn:

- No body disintegration or deformation could be detected after 25 of freeze-thaw cycles.

- Influence of freeze and thaw test on the weight loss of NZ-based geopolymer mortar is larger than that on the weight loss of GGBS- and FA- based geopolymer mortars.

- The residual compressive strength of all specimens were lower than the values obtained for specimens not subjected to any freeze-thaw resistance test, except those containing GGBS. The residual compressive strength values of NZ-based geopolymer mortars were found to be lower than the residual compressive strength values of FA- and GGBS- based mortars. 
- A slight lightening of color was observed in the specimens after the exposure, especially to $600^{\circ} \mathrm{C}$ and then the color of specimens turned into white after exposure to $900^{\circ} \mathrm{C}$.

- The most weight losses were observed in GGBS specimens exposed to high temperature effects. The addition of $50 \%$ FA and GGBS to NZ-based mortar reduced the weight loss of specimens exposed to high temperature effects.

- The minimum compressive strength was obtained at $900^{\circ} \mathrm{C}$ for all mixes. The residual compressive strength of NZ-based mortars after their heat treatment is relatively higher than that of the mortars on the basis of FA and GGBS.
- The $\mathrm{Na}_{2} \mathrm{SiO}_{3} / \mathrm{NaOH}$ ratios of the alkaline activator solution used to prepare the geopolymer mortars have an effect on the weight losses and residual compressive strengths of the specimens subjected to high temperatures and freeze-thaw test. As the $\mathrm{Na}_{2} \mathrm{SiO}_{3} / \mathrm{NaOH}$ ratios increased, the weight and strength losses decreased.

- The primary component of geopolymer mortar is industrial by-products (FA and GGBS) and producing geopolymer mortars is relatively inexpensive. In addition, the production of geopolymer mortars does not generate harmful greenhouse gas emissions and is therefore considered environmentally friendly.

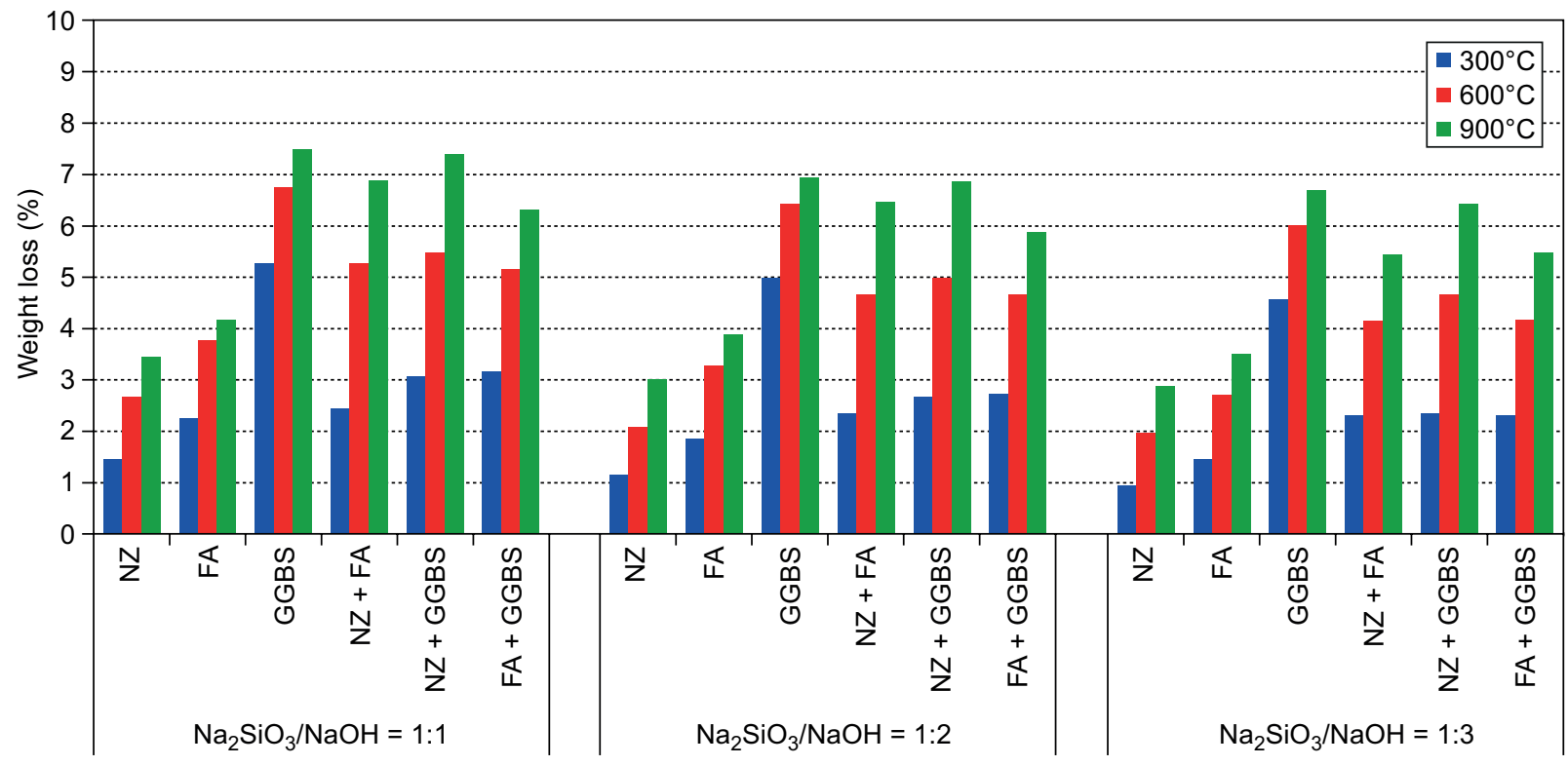

Figure 7. Weight loss of geopolymer mortars after exposed high temperatures.

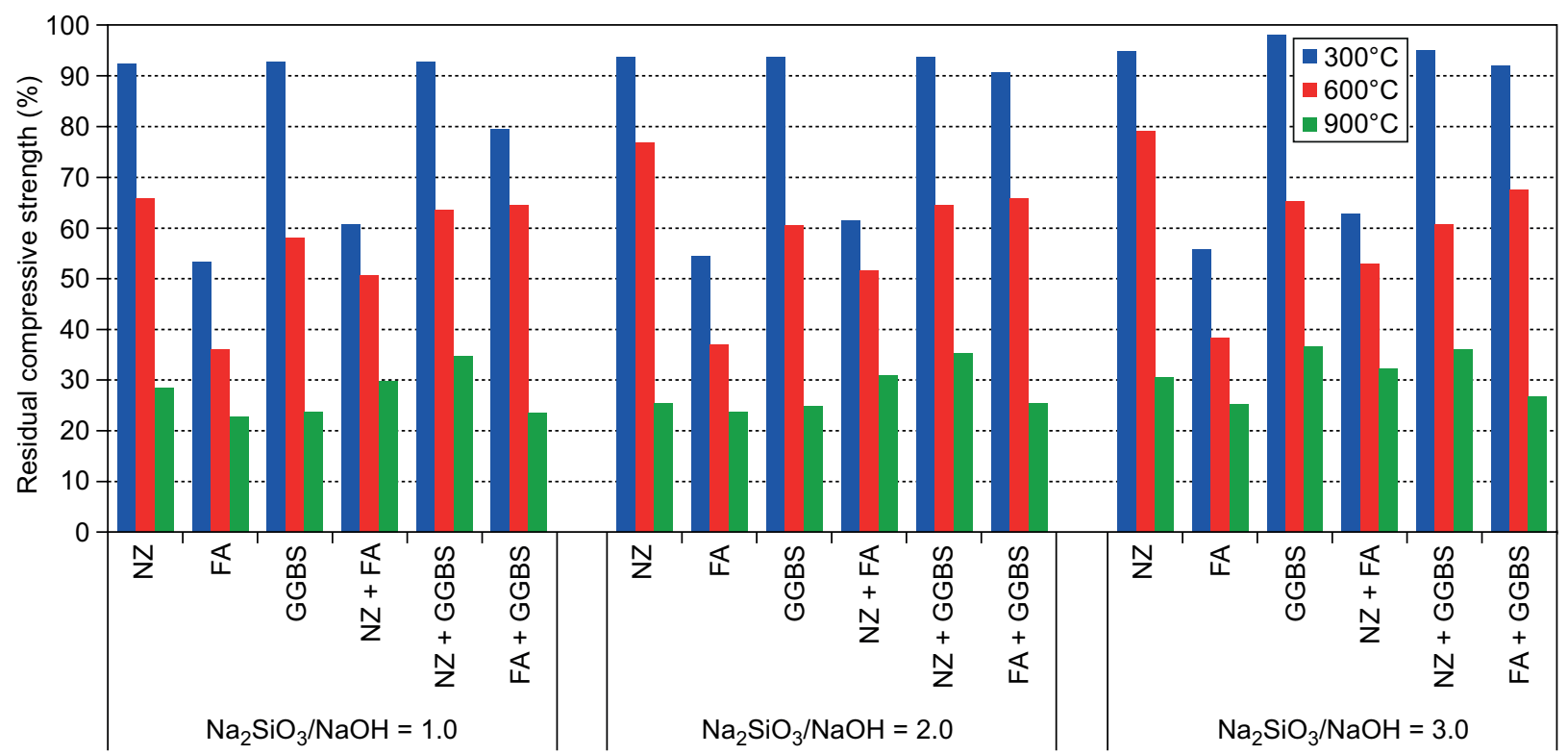

Figure 8. Residual compressive strength of geopolymer mortars after exposed high temperature. 
Acknowledgements

This research has been carried out under the project of BAP.2016.0001 in the framework Balikesir University Scientific Research Projects Coordination Department

\section{REFERENCES}

1. Mehta P.K. (2001): Reducing the environmental impact of concrete. Concrete International, 23(10), 61-66.

2. Malhotra V.M. (2010): Global warming and role of supplementary cementing materials and superplasticizers in reducing greenhouse gas emissions from the manufacturing of portland cement. International Journal of Structural Engineering, 1(2), 116-130. doi: 10.1504/IJStructE. 2010.03148

3. Davidovits J. (2013). Geopolymer cement: A review. Geopolymer Institute, Saint-Quentin, France.

4. Duxson P, Provis J.L., Lukey G.C., Van Deventer J.S.J. (2007): The role of inorganic polymer technology in the development of 'green concrete'. Cement and Concrete Research, 37, 1590-1597. doi: 10.1016/j.cemconres.2007. 08.018

5. Fernandez-Jimenez A., Palomo J.G., Puertas F. (1999): Alkali-activated slag mortar mechanical strength behaviour. Cement and Concrete Research, 29(8), 1313-1321. doi: 10.1016/S0008-8846(99)00154-4

6. Hardjito D., Rangan B. V. (2005). Development and Properties of Low-Calcium Fly Ash-Based Geopolymer Concrete. Research Report GC1, Curtin University of Technology, Australia.

7. Bakharev T. (2005): Geopolymeric materials prepared using Class $\mathrm{F}$ fly ash and elevated temperature curing. Cement and Concrete Research, 35(6), 1224-1232. doi: 10.1016/j.cemconres.2004.06.031

8. Atis C.D., Bilim C., Celik O., Karahan O. (2009): Influence of activator on the strength and drying shrinkage of alkaliactivated slag mortar. Construction and Building Materials, 23, 548-555. doi: 10.1016/j.conbuildmat.2007.10.011

9. Villa C., Pecina E.T., Torees R., Lauren Y Gomez- Zamorano. (2010): Geopolymer synthesis using alkali activation of natural zeolite. Construction and Building Materials, 24(11), 2080-2090. doi: 10.1016/j.conbuildmat.2010.04. 052

10. Nikolov A., Rostovsky I., Nugteren H. (2017): Geopolymer materials based on natural zeolite. Case studies in Construction Materials. 6, 198-205. doi: 10.1016/j.cscm.2017. 03.001

11. Parthiban K, Saravana R.M.K. (2014): Effect of sodium hydroxide concentration and alkaline ratio on the compressive strength of slag based geopolymer concrete. International Journal of ChemTech Research, 6(4), 2446-2450.

12. Patankar S.V., Ghugal Y.M., Jamkar S.S. (2014): Effect of concentration of sodium hydroxide and degree of heat curing on fly ash-based geopolymer mortar. Indian Journal of Materials Science, 938789. doi: 10.1155/2014/938789.

13. Aydin S., Baradan B.(2014): Effect of activator type and content on properties of alkali-activated slag mortars. Composites: Part B, 57, 166-172. doi:10.1016/j.compositesb. 2013.10.001

14. Abdi Omer S., Demirboga R., Khushefati W.H. (2015): GGBFS based geopolymer mortars immersed in sodium and magnesium sulfate solutions and sea water. International Journal of Engineering Research and Technology (IJERT), 4(2), 377-384.

15. Zarina Y., Mustafa Al Bakri A.M.A., Kamarudin, H., Khairul Nizar, I., Razak R.A., Andrei, V.S.(2015): Effect of solids-to-liquids, $\mathrm{Na}_{2} \mathrm{SiO}_{3}$-to- $\mathrm{NaOH}$ and curing temperature on the palm oil boiler ash $(\mathrm{Si}+\mathrm{Ca})$ geopolymerisation system. Materials, 8, 2227-2242. doi:10.3390/ma8052227

16. Dolezal J., Skvara F., Svoboda P., Sulc R., Kopecky L., Pavlasova S., Myskova L., Lucuk M., Dvoracek K. (2007): Concrete based on fly ash geopolymers. in: Proceedings of Alkali activated materials - research, production and utilization. Prague, Czech Republic; pp. 185-197.

17. Yunsheng Z., Wei S. (2006): Fly ash based geopolymer concrete. Indian Concrete Journal, 80, 20-24.

18. Krivenko P.V. (1999). Alkali cements: Structure, properties, aspects of durability. in: Proceedings of the Second International Conference on Alkali Cements and Concretes, Kiev, Ukraine.

19. Bortnovsky O., Dvorakova K., Roubicek P., Bousek J., Prudkova Z., Baxa P. (2007): Development, properties and production of geopolymers based on secondary raw materials. in: Proceedings of Alkali activated materials - research, production and utilization. Prague, Czech Republic. pp. 83-96.

20. Brooks R., Bahadory M., Tovia F., Rostami H. (2010): Properties of alkali-activated fly ash: high performance to lightweight. International Journal of Sustainable Engineering, 3(3), 211-218. doi: 10.1080/19397038.2010. 487162

21. Heng S. (2013): A Preliminary Research on alkali -activated slag concrete as tunnel lining in severe firigid regions. Advanced Materials Research, 668, 65-69. doi:10.4028/ www.scientific.net/AMR.668.65

22. Bakharev T.(2006): Heat resistance of geopolymer materials prepared using class F fly ash. Journal of Australian Ceramic Society, 42(1), 36-44. doi: 10.1016/j.cemconres. 2006. 03.022

23. Kong D.L.Y., Sanjayan J.G. (2010): Effect of elevated temperatures on geopolymer paste, mortar and concrete. Cement and Concrete Research, 40, 334-339. doi: 10.1016/ j.cemconres.2009.10.017

24. Hussin M.W., Bhutta M.A.R., Azreen M., Ramadhansyah P.J., Mirza J. (2015): Performance of blended ash geopolymer concrete at elevated temperatures. Materials and Structures, 48, 709-720. doi: 10.1617/s11527-014-0251-5

25. Topcu I.B., Toprak M.U. (2011): Properties of geopolymer from circulating fluidized bed combustion coal bottom ash. Materials Science and Engineering A, 528(3), 1472-1477. doi: 10.1016/j.msea.2010.10.062

26. Skvara F., Kopecky L., Smilauer V., Alberovska L., Vinsova L. (2009): Aluminosilicate polymers - influence of elevated temperatures, efflorescence. Ceramics-Silikaty, 53, 276-282.

27. Skvara F., Jilek T., Kopecky L. (2005): Geopolymer materials based on fly ash. Ceramics-Silikáty, 49(3), 195-204.

28. Thang N.X. (2016): Influences of high temperatures and environmental conditions on mechanical properties of geopolymer mortar based on fly ash. International Journal of Engineering Research and Technology (IJERT), 5(1), 148-154.

29. Pan Z., Sanjayan J.G., Collins F. (2014): Effect of transient creep on compressive strength of geopolymer 
concrete for elevated temperature exposure. Cement and Concrete Research, 56, 182-189. doi: 10.1016/j.cemconres. 2013.11.014

30. Krivenko P, Guziy S. (2007). Fire resistant alkaline Portland cements. In: Proceedings of Alkali activated materials-research, production and utilization. Prague, Czech Republic, pp. 333-347.

31. ASTM Standard C618-94a (1994). Standard specification for coal fly ash and raw or calcined natural pozzolan for use as a mineral admixture in Portland Cement concrete. Annual Book of ASTM Standards, Vol. 04.02. ASTM, Philadelphia.

32. Turkish Standard Institute-TS EN 15167-1(2006): Ground granulated blast furnace slag for use in concrete, mortar and grout-Part 1: definitions, specifications and conformity criteria. TSI, Ankara.

33. Turkish Standard Institute-TS EN 196-1(2009): Methods of testing cement-Part 1: Determination of strength. TSI, Ankara.

34. ASTM Standard C230M-14 (2014). Standard specification for flow table for use in tests of hydraulic cement. American Society for Testing and Materials, Philadelphia

35. ASTM C109 / C109M-16a, Standard test method for compressive strength of hydraulic cement mortars (Using 2-in. or [50-mm] cube specimens), ASTM International, West Conshohocken, PA, 2016.

36. Glukhovsky V.D. (1979). Alkaline and Alkaline-Alkaliearth Hydraulic Binders and Concretes, Kiev: USSR, Vysscha Shkola Publisher/

37. Zuda L., Rovnanik P., Bayer P., Cerny R., (2008): Effect of high temperatures on the properties of activated aluminosilicate with electrical porcelain filler. International Journal of Thermophysics, 29(2), 693-705. doi: 10.1007/ s10765-007-0311-y

38. Türkmen I., Karakoc M.B., Kantarcı F., Maraş M.M., Demirboğa R. (2016): Fire resistance of geopolymer concrete produced from Elazığ ferrochrome slag. Fire and $m a-$ terials, 40(6), 836-847. doi: 10.1002/fam.2348

39. Zhang B., Bicanic N. (2002): Residual fracture toughness of normal and high strength gravel concrete after heating to $600{ }^{\circ} \mathrm{C}$. ACI Materials Journal, 99(3), 217-226.

40. Pavithra P., Srinivasula Reddy M., Dinakar P., Hanumantha Rao B., Satpathy K., Mohanty A.N. (2016). Effect of the $\mathrm{Na}_{2} \mathrm{SiO}_{3} / \mathrm{NaOH}$ Ratio and $\mathrm{NaOH}$ Molarity on the Synthesis of Fly Ash-Based Geopolymer Mortar.in: Conference: Geo-Chicago 2016. pp.336-344. doi: 10.1061/ 9780784480151.034 